\section{IJ§ER}

ISSN: $2149-5939$
International Journal of Social Sciences and Education Research

Online, http://dergipark.gov.tr/ijsser

\title{
The effect of cooperative learning on primary-elementary pre-service teachers' academic achievement in Turkey: A systematic review
}

\author{
Nevin Avc1 ${ }^{1}$ and Meral Aksu ${ }^{2}$
}

Received Date: 16 / $01 / 2019$

Accepted Date: 27 / 03 / 2019

\begin{abstract}
The aim of this study is to depict the effect of Cooperative Learning (CL) on primary-elementary pre-service teachers' academic achievement in Turkey in a systematic review. With respect to this aim, as Turkey adopted Constructivism in education in 2005 which is the major theory underlying CL, as a time span the search was confined to the literature between 2005 and 2018. Major search data bases scanned were ULAKBIM, ERIC, Metulib, MetUnique, J-STOR, Google Scholar, EPÖDER, DergiPark and tezYÖK (national database for accessing theses). As a result of this search, based on pre-determined criteria, thirteen (13) studies are included into the review. The themes emerging are as (a) comparison of cooperative learning (CL) with traditional methods (TMs), (b) comparison of different methods of CL, (d) Jigsaw as a CL method. As a result of the review, CL is found to have a significant effect on primary-elementary pre-service teachers' academic achievement in Turkey.
\end{abstract}

Keywords: Cooperative learning, Academic achievement, Primary-elementary pre-service teachers, Systematic review

\section{Introduction}

Cooperative learning (CL) refers to "classroom techniques in which students work on learning activities in small groups and receive rewards or recognition based on their group's performance" (Slavin, 1980, p. 315). Varied researches conducted to investigate the factors influencing students' academic achievement, motivation, attitudes and so forth indicate that cooperative learning is one of the most effective instructional strategies (Walber, 1986; Najmonnisa \& Saad, 2017 , p. 3). At the very center of CL lays there that students learn "in small heterogeneous groups to achieve a shared learning goal" facilitating learning needs of diverse learners (Nuntrakune, Nason \& Kidman, 2006; Stainbank, 2009; Hossain \& Ahmad, 2013; Altun, 2015; Chai, Tay \& Lim, 2015; Buchs \& Butera, 2015; Casey, Goodyear \& Dyson, 2015; Lirola, 2016; Phiwpong \& Dennis, 2016; Rajab \& Ibrahim, 2017; Najmonnisa \& Saad, 2017, p. 3).

Up to recent years, Turkey did not have a specifically defined problem in relation to the diversity and multicultural classrooms at schools. Yet, recent socio-political dynamics changing the infrastructure in the middle east led Turkey to take serious numbers of refugees in, that paved the vay of triggering the dynamics of education needed to be taken into account seriously calling for precautions, as well as social, political and cultural areas. So, teachers in actual classrooms are to learn how to cope with this new situation and improve the learning outcomes of her/his learners. The literature in this sense supports CL as a remedy with evidence-based studies. For instance, in culturally diversified classrooms, when students get the chance of interacting with one another, they learn how to learn together, respect each other and appreciate this

${ }^{1}$ Ministry of National Education, Metropolitan Municipality of Sakarya, Turkey, nevinavci06@gmail.com ${ }^{2}$ Middle East Technical University, Ankara, Turkey, aksume@metu.edu.tr 
Avc1, N., Aksu, M. (2019). The effect of cooperative learning on primary-elementary pre-service teachers' academic achievement in Turkey: A systematic review. International Journal of Social Sciences and Education Research, 5(2), 122-141.

diversity and "add color to classroom life" (Johnson, Johnson, Stanne \& Garibaldi, 1990; Schwieger, Gros \& Barberan, 2010; Hossain \& Ahmad, 2013). In addition to the diversity of cultures, in case of diversity of abilities as well, when students are put together in heterogeneous groups, they both have the chance to interact with one another, and by enhancing each other's' learning to achieve a shared goal. The literature shows that as opposed to lecture-based teaching which promotes individualistic learning styles segregating learners from each other, based on competition for grades; CL as collective group performances improve both contents understanding and academic grades. At this very point, keeping in mind the fact that there is no best strategy or method fitting for all educational settings, as an integrative strategy CL seems promising to help understanding the factors influencing learning in multicultural classroom environments rather than the segregate traditional methods utilized in this case. That means, in other words, as the world is globalized in a hectic speed, the $21^{\text {st }}$ century teachers need to keep up with the changes coming forward. These changes reveal themselves as needs that teachers are to be equipped with, particularly before going into the actual classrooms.

As a result of the search in the Turkish literature, most teacher education programmes seem to have incorporated $\mathrm{CL}$ as an instructional strategy on the pre-service teacher education which is promising for equipping the teachers with the required innovative skills. In this sense, this review aims to depict the effect of CL on primary-elementary pre-service teachers' academic achievements in Turkey. The reason of using "primary-elementary pre-service teachers" in the title of the study is the education reform which was a transition from eight-year non-stop compulsory education to $4+4+4$ in 2012 as the study involves studies from both periods (MoNE, 2012).

\section{Literature}

Within theoretical perspectives, cooperative learning instructional strategy is deeply rooted in social constructivism, cohesion and motivational theories (Alzahrani, 2016; Najmonnisa \& Saad (2017). Constructivist theories in common consider knowledge as socially constructed and the beginning of a new learning is based on cognitive conflict (Najmonnisa \& Saad, 2017, p. 3).

Though researchers quite reach a consensus with regard to the positive effects of CL, the questions of why and how CL affect achievement and under what conditions this effect occurs still is a controversial issue. In this sense, the best known Slavin (1995) identified motivationalist, social cohesion, cognitive developmental and cognitive elaboration theories on achievement effects of CL.

Motivationalist perspective takes "task motivation" central and asserts that other processes of planning and helping are led by the motivated self-interest of the individuals. The advocates of this perspective put emphasis on reward or goal structure, and further claim that under some circumstances interaction is not obligatory for the learning outcomes of CL to be manifested (Slavin, 1995; Slavin, 2011, p. 345).

By stark contrast, the social cohesion perspective which is also known as social interdependence theory interprets the effects of CL as dependent on the social cohesiveness of the group. In this perspective, learners help each other learn and care about their groups (Johnson \& Johnson, 1998; Slavin, 2011, p. 345). 
Avc1, N., Aksu, M. (2019). The effect of cooperative learning on primary-elementary pre-service teachers' academic achievement in Turkey: A systematic review. International Journal of Social Sciences and Education Research, 5(2), 122-141.

The cognitive perspectives assert that the interaction is of central importance in increasing student achievement "for reasons which have to do with mental processing of information rather than motivation". In cognitive developmental perspective interaction among learners on appropriate tasks is fundamental to increase their mastery of critical concepts which is related to Vygotsky's (1978, p.86) zone of proximal development underlying the importance of "collaboration with more capable peers" and to Piaget's (1926) view supporting that the social arbitrary knowledge such as values, rules, morality can merely be learnt via by interacting with others. Cognitive elaboration, on the other hand, goes one step further and asserts that "if information is to be retained in memory and related to information already in memory, the learner must engage in some sort of cognitive restructuring, or elaboration of the material" (Wittrock, 1986; Slavin, 2011, p. 351).

\subsection{Cooperative learning methods}

At this part, CL methods are given under Student Team Learning (STL) and Informal Group Learning (IGL) methods. STL techniques are a product of the researches by Slavin $(1994,1995)$ at John Hopkins University. The common idea in all the methods is that learners "work together to learn and are responsible for one another's learning as well as their own". Team goals and teams' achievement are central to STL methods (Slavin, 2011, p.353). That is, the goals can be achieved only if all the members of the teams learn the objectives. Therefore, in STL, "the students' task is not to do something as a team but to learn something as a team" (Slavin, 2011, p.353).

There are four major STL methods that will be given here as a product of Slavin's extensive researches. The first two are Student Team-Achievement Divisions (STAD) and Teams-GamesTournament (TGT) which are suggested being adaptable almost for all subjects and all grades. The rest which are Team-Assisted Individualization (TAI) and Cooperative Integrated Reading and Composition (CIRC) are stated as being more appropriate for the use of particular subjects and grades. While the former is stated to be more appropriate for Maths at years 3-6, the latter is more appropriate for reading and writing instruction at years 3-5.

Teams-Games-Tournaments: In this method, there are two major features to be underlined; 4-5 member student teams, and instructional tournaments. The key cooperative element is "teams" in TGT. Students are assigned to the teams in a way that maximizes heterogeneity of ability, sex and race. The principal function of the team is to prepare its members for the tournament. The teacher's presentation of the topic is followed with the provision of the learners with worksheets containing academic content similar to that will be in the tournament. The members of the teams study and quiz each other till they are sure that the content is learnt. The tournaments usually are held once each week and for fair competition, the students are assigned to three-person tables systematically. The three students with the highest performance are assigned to Table 1, the next three to Table 2 and so on. As students are assigned to "abilityhomogeneous" tables, they have equal chance to contribute in maximum performance to their teams. Students at the tables represent their teams and the score they earn is added to their teams. After the tournament the teacher announces the successful teams and first place scorers. While team assignments remain the same, based on the past performances the students at the tournament tables may change to maintain equality (Slavin, 1980, p. 320). 
Avc1, N., Aksu, M. (2019). The effect of cooperative learning on primary-elementary pre-service teachers' academic achievement in Turkey: A systematic review. International Journal of Social Sciences and Education Research, 5(2), 122-141.

Student Teams-Achievement Divisions (STAD): the students in STAD, similar to TGT are assigned to 4-5 member groups while the tournaments are replaced with 15 minute quizzes. Again, the scores students get are translated to team scores called "achievement divisions". Scoring of the quizzes are done in a similar way with TGT based on a way of abilityhomogeneous reference to give equal chance to students to contribute to their divisions, the highest six students are compared based on past performance. While the top scorer gets eight points to his team, the second gets six points and so forth. Via this way, students are compared to the homogeneous ability group rather than the entire class. And the equality of opportunity is set for the students to contribute to their teams similar in the way it is in TGT (Slavin, 1980, p. $320)$.

Team Assisted Individualization (TAI): the common feature of TAI with the formerly introduced methods is that, TAI also uses four-member mixed ability learning teams and certificates for high performing teams. Different from TGT and STAD, TAI combines cooperative learning with individualized instruction (Slavin, 2011, p. 355). This method was developed by Slavin, Leavey and Madden (1984) particularly for math courses. Initially, students are placed to their team as a result of the placement test and then they proceed at their own pace. Usually, the team members work on different units, and members in the team help each other and check each others' work.

Cooperative Integrated Reading and Composition (CIRC): is a method that is put forward more to develop reading and writing skills as well as speaking and listening skills in upper classes in elementary schools. CIRC supports using reading texts and reading groups much as it is in traditional teacher-centered approach (Aç1kgöz, 1992; Varışoğlu, 2016, p. 1169). Yet, it is different from traditional ones in the way that all students are assigned to teams composed of two pairs from two different groups. Thanks to the nature of the method, while the teacher is engaged in helping one group, the other groups engage in deep cognitive activities such as summarizing stories to one another, spelling, decoding vocabulary, revising and editing one another's work. The quiz is not provided to the student until the team determine that their member is ready to take it. Certificates are given to teams based on the average performance of the all members in the group (Slavin, 2011, p. 355).

Peer-Assisted Learning Strategies (PALS): is a method that is found to be more effective at elementary and middle school math and reading. In this method, the learners in a dyadic fashion take turns as teacher and students helping each other learn, rewarded based on the leaning of both students' (Slavin, 2011, p. 356).

In this part, shortly, the Informal Group Learning Methods are presented.

Jigsaw: similar to TGT and STAD, students in Jigsaw are assigned to heterogeneous groups. The academic material to be taught is divided into segments as many as there are members in the teams. For instance, the CL methods covered in this section can be divided into two per student as there are eight in total for each team. The students study their part with the members in the other teams as experts of that part and return to their own team to teach his/her part. Finally, all members are tested on the entire unit. Different from TGT and STAD, the test scores are for the sake of individual grades not for the team. In this sense, Jigsaw is high in task interdependence, low in reward interdependence because individual performances do not contribute in a direct way to group goal (Slavin, 2011, p. 356). 
Avc1, N., Aksu, M. (2019). The effect of cooperative learning on primary-elementary pre-service teachers' academic achievement in Turkey: A systematic review. International Journal of Social Sciences and Education Research, 5(2), 122-141.

A variation of Jigsaw is Jigsaw II developed by Slavin (1994) in which students all read the same material but focus on different segments. Then the procedure is the same except for the quiz scores. Different from Jigsaw I, the individual scores are added to form team scores like in STAD and TGT. Thus, Jigsaw II is less task interdependent and more reward interdependent (Slavin, 1980, p. 321).

Learning Together (LT): is a method developed by David Johnson and Roger Johnson (1998) in Minnesota. Students in groups of four or five heterogeneously assigned work together on an assignment sheet and submit a single sheet upon which receive praise and rewards based on the group product (Slavin, 2011, p. 357).

Group Investigation (GI): is a method developed by Shlomo Sharan and Yael Sharan (1992) at the university of Tel-Aviv in which students form their own two to six-member groups. In this method, from the entire class unit, the groups choose a subtopic and break their subtopics into individual tasks and prepare a single report. Finally, each group presents their topic to the whole class and communicate the findings (Slavin, 2011, p. 357).

In addition, two other methods are as follow:

Ask Together-Learn Together (ATLT): developed by Açıkgöz (1990), this method is based on "sheer cooperation" among learners and puts "utmost importance on positive interdependence within group, individual accountability, group processing, and face to face promotive interaction". The method is based on the steps as follow: (a) organization of the groups is done heterogeneously ideally consisting 3-4 learners, (b) in the reading step, students read the text silently and individually, the teacher highlights important parts, (c) in the preparation of the learner' questions the students write questions about the text on a card, (d) in preparation of group questions the members come together to prepare the group questions, (e) in sending group questions, the questions prepared together as a group are sent to another group randomly, (f) in responding to group questions step, each group has one question increasing interdependence, ( $\mathrm{g}$ ) in presenting responses to the class, a spokesperson chosen either by the group or the teacher the answer is communicated to the class, (h) in evaluating group presentations step the performance of the spokesperson is evaluated by the teacher or other students, the teacher may provide a form for this. The score is translated to the groups' score, (j) in whole-class discussion step, after the presentations, the teacher to clarify untouched points can initiate a discussion, or give a summary, (i) in the testing step all students take an exam individually and the scores of the exams, presentations are summed up and translated into groups' scores. The groups are given rewards by comparing group scores to pre-determined criteria like "very good", "good", "not bad" (Bölükbaş, Keskin \& Polat, 2011, p. 331).

Reading-Writing-Presenting (RWP): this method is composed of three steps. The first step is reading in which the students are given reading text from different resources about the topic (Aksoy \& Doymus, 2011; Alyar, 2014, p. 26). In writing as the second step, the students bring together what they have learnt in the form of a report together with the members of their groups. In presenting (which is known also as application), step students present their reports to the class, the teacher intervenes if necessary for clarification (Alyar, 2014, p. 26).

To sum, CL has many methods and techniques in the literature. Therefore, in this part of the study, the major methods were presented that occupy a central place in the worldwide research- 
Avc1, N., Aksu, M. (2019). The effect of cooperative learning on primary-elementary pre-service teachers' academic achievement in Turkey: A systematic review. International Journal of Social Sciences and Education Research, 5(2), 122-141.

es and the Turkish literature particularly in an inclusive fashion of the methods used in the studies taken to this review.

\subsection{A typology of cooperative learning methods}

The methods presented differ from each other mainly based on five dimensions which are reward interdependence, task interdependence, individual accountability, teacher-imposed structure and use or nonuse of group competition based on Slavin's (1980) typology.

High reward interdependence means that there will certainly be a group reward at the end as a result of group performance while low reward interdependence means that students are asked to work together and are praised as a group, yet group performance does not lead to a concrete goal like in the case of Jigsaw I as the scores are counted individually at the end. However, the task interdependence is high for Jigsaw as students cannot achieve well in the quizzes if the teammates do not teach them well which means in task interdependence students must rely on one another to do their group tasks. Contrary to this, in low task interdependence students may choose to work alone without disrupting the others.

High individual accountability dimension, on the other hand, means that each student's contributions to the team's achievement is quantifiable like it is in TGT and STAD. This dimension forms a prevention of the over workload for some members and helps fair scoring. The opposite of individual accountability is substitutability in which students can substitute one another to do the tasks.

In addition to this, teacher-imposed structure represents the "degree to which tasks, rewards and schedules" are imposed by the teacher or the method itself. And the opposite of teacherimposed structure refers to high student autonomy like it is in Group Investigation method.

Finally, group competition refers to a prize or recognition to the highest scoring groups in the class as presented in Table 1 modified from the original typology formed by Slavin (1980), to present the methods discussed in this study.

Table 1. Characteristics of cooperative learning methods modified from the original Table by Slavin (1980), p. 323)

\begin{tabular}{lccccc}
\hline Methods & $\begin{array}{c}\text { Reward interde- } \\
\text { pendance }\end{array}$ & $\begin{array}{c}\text { Task interdepend- } \\
\text { ence }\end{array}$ & $\begin{array}{c}\text { Individual } \\
\text { accountability }\end{array}$ & $\begin{array}{c}\text { Teacher } \\
\text { imposed } \\
\text { structure }\end{array}$ & $\begin{array}{c}\text { Use of group } \\
\text { competition }\end{array}$ \\
\hline TGT & High & Low & High & High & Yes \\
STAD & High & Low & High & High & Yes \\
TAI & High & Low & High & High & Yes \\
CIRC & High & High & High & High & Yes \\
Jigsaw I & Low & High & High & High & No \\
Jigsaw II & High & High & High & High & Yes \\
LT & Low & Low & Low & Low & No \\
GI & Low & High & High & Low & No \\
AT-LT & High & Low & Low & High & Yes \\
RWP(A) & Low & Low & Low & Low & No \\
\hline
\end{tabular}

As Jolliffe and Snaith (2017) state, despite evidence-based benefits of working together cooperatively (Jenkins et al. 2003; Johnson \& Johnson 1989; Kyndt et al. 2013; Sharan 1990; 
Avc1, N., Aksu, M. (2019). The effect of cooperative learning on primary-elementary pre-service teachers' academic achievement in Turkey: A systematic review. International Journal of Social Sciences and Education Research, 5(2), 122-141.

Slavin 1995), the use of cooperative learning in classrooms throughout the world is limited (Fernández-Lozano, González-Ballesteros \& De-Juanas 2012; Ruys, Van Keer \& Alterman 2012; Veenman et al. 2002). Large scale studies by Galton et al. in 1980 repeated in 1999; the study of Baines, Rubie-Davies, and Blatchford 2009; assert that in the majority of the primary classrooms, students are put together to sit but "they rarely work together as groups" (Jolliffe \& Snaith, 2017, p. 308). One of the reasons of this situation is suggested as the lack of professional development of teachers. Also, as is asserted by Slavin (2008) upon a research on elementary level, "many teachers had difficulty adapting cooperative learning methods to their traditional textbooks and objectives" (p. 152). As is noted by Fernández Lozano, González-Ballesteros and De-Juanas (2012), without learning about cooperative learning and experiencing it during their initial teacher education, pre-service teachers will be less likely to adopt cooperative learning in their classrooms and would quit using it if they are encountered with difficulties in implementing it (Jolliffe \& Snaith, 2017, p. 308).

To sum up, as stated by Slavin (2011), within time CL has focused on a wide variety of outcomes based on academic achievement in many subjects. As is stated earlier cooperative learning is of remarkable importance for initial teacher education programs as one of the aims of teacher education and professional development is to enable teachers "engage in long term implementation of the procedures being taught" (Johnson \& Johnson 1994a; Johnson \& Johnson, 2017, p. 284). In this sense, in the study, the effect of CL is reviewed on primary-elementary pre-service teachers' academic achievement in Turkey. With regard to this aim the research question asked is comprised of: "Does CL have an effect on primary-elementary pre-service teachers' academic achievement in Turkey?"

As it is aimed to depict the effect of CL on primary-elementary pre-service teachers' academic achievement, the study is supposed to contribute the national literature in the sense of providing a through and concise study in a local manner of Turkey. The study also would aid to shed light onto the initial teacher-education programs implemented from the perspective of CL on academic achievement. Besides, the study would be helpful for the researchers to carry out further systematic reviews in terms of instructional strategies with different perspectives. Therefore, in a mirror-like fashion, the study intends to reflect what is on and not in terms of achievement in primary-elementary teacher education programs in line with CL in Turkey starting from the radical change of adopting Constructivism in 2005 up to today.

\section{Method}

In order to find the related articles to reach the eligible ones about the effect of CL on preservice teachers' learning outcomes as achievement on primary-elementary level, a broad search was carried out. The time interval of the study is confined to 2005-2018 and the review was framed with the studies that came out within 14 years which is a fairly long-time interval to evolve an overall perspective up to today. The rationale behind the time interval was related to the educational reform in adopting Constructivism in primary education all over the country as an educational approach in 2005 in Turkey, which is the major theory grounding CL as an instructional strategy (Çınar, Teyfur \& Teyfur, 2006, p. 48).

As for accessing the related studies the mostly used data bases were searched. As the priority is given to the published academic articles, initially the article databases such as ULAKBİM, 
Avc1, N., Aksu, M. (2019). The effect of cooperative learning on primary-elementary pre-service teachers' academic achievement in Turkey: A systematic review. International Journal of Social Sciences and Education Research, 5(2), 122-141.

ERIC, Metulib, MetUnique, J-STOR, Google Scholar, EPÖDER and DergiPark, were scanned. The keywords used to retrieve the related studies were "cooperative learning", "cooperative learning and pre-service teachers", "cooperative learning and elementary pre-service teachers", "cooperative learning and primary pre-service teachers". Not to miss a study, the keywords were even extended to "cooperative learning at higher education/tertiary level" for the possibility of some studies being tagged as higher education instead a more specific definition representing "pre-service teachers". In addition, keywords were replaced with Turkish equivalents like "işbirlikli öğrenme”, "kubaşı öğrenme”, "iş birlikli öğrenme ve öğretmen adayları” etc. to retrieve every possible study.

Secondly, to retrieve the related theses, the data base of tezYÖK (national database to access theses) was scanned, also as a crosscheck for the duplicates as some of the theses' article versions would have been released.

In addition, the reference pages of the articles and theses were scanned as an assurance to eventually include all the related accessible studies. After screening all the aforementioned databases including all the pages related and by the crosscheck of each with the other data bases, the search was ended. The last date accessed the data bases was $10^{\text {th }}$ January 2019. Although the search was handled meticulously and cautiously, still there might be the possibility of not having included a relevant study in the scope of this review.

\subsection{Inclusion criteria}

In order to sustain coherence and relevance in the study, the articles were included into the review according to the criteria determined as follow: Articles or theses were to be included into the review only if;

1. Conducted in Turkish educational settings,

2. Conducted in a Faculty of Education in Turkey,

3. Conducted in elementary school or primary school teaching departments between 20052018 ,

4. Conducted in order to examine the effects of CL on academic achievement of preschool teachers.

As the first initiative, the identification of cooperative learning showed that there were 165.319 titles and abstracts at the major data bases in the overall literature.

When framed with the $1^{\text {st }}$ criterion, 8558 articles and 283 theses were found conducted in Turkish educational settings about cooperative learning.

When the $2^{\text {nd }}$ criterion was run, 41 ( 31 articles, $2 \mathrm{PhD}$ dissertations, $8 \mathrm{MA}$ theses) studies were found be relevant having been conducted in a Faculty of Education in Turkey. Therefore, studies in different departments like nursing, engineering, administration, psychological counseling and guidance and accounting were excluded.

Upon screening the studies based on the $3^{\text {rd }}$ criterion, 19 articles and 5 theses $(2 \mathrm{PhD}$ dissertations, 3 MA theses) were found to have been conducted in elementary school or primary school teaching departments between 2005-2018. Sticking to the criteria, studies conducted before 2005 as well as in pre-school, secondary education departments were excluded. In addi- 
Avc1, N., Aksu, M. (2019). The effect of cooperative learning on primary-elementary pre-service teachers' academic achievement in Turkey: A systematic review. International Journal of Social Sciences and Education Research, 5(2), 122-141.

tion, studies including pre-service teachers studying in the programmes that could both work at secondary and elementary schools such as foreign languages, music education, physical education and art departments were excluded as MoNE still has not go into a division for those programmes. That is, studies conducted only at "primary-elementary school teaching departments of Turkish, Maths, Science, Social studies" were included into the review to present a feasible systematic analysis.

Finally, when the $4^{\text {th }}$ criterion was run, 13 articles $(n=13)$ were determined as eligible meeting the whole criteria to be included in the review as the final criterion requires studies only conducted to examine the effects of CL on academic achievement of primary-elementary preschool teachers. So, studies that searched for additional variables besides academic achievement such as "academic achievement and retrieval, retention, attitudes, perceptions" were excluded. Also, the studies on skill improvements such as "science process skills, writing skills and cognitive skills" were excluded. As a result, 13 studies based on purely academic achievement were included into the review for having a well-tailored, and more eligible systematization of the analysis.

\subsection{Data analysis}

As the studies included into the review were investigating the effect of CL on pre-service teachers' achievement, the studies were quantitative studies of which 11 of them were quasiexperimental $(n=11)$ and two were experimental designs $(n=2)$ in design. Via the Table 2 provided (see Appendix 1), the quantitative studies were classified according to the emerging themes including detailed information about the authors, year of publication, method, purpose \& context \& sample, results and themes.

During the classification of studies retrieved to the study, as a result of scrutinizing the articles to give impeccable details systematically, three themes emerged which are (a) comparison of CL with traditional methods (TMs); (b) comparison of different methods of CL and (c) Jigsaw as a CL method. In addition to this, as some studies, alongside their major theme, represented a second theme as well, they were simultaneously reviewed under both themes.

\section{Results}

All 13 studies reviewed, study the impact of CL on pre-service teachers' academic achievement who were studying at primary education or elementary level departments of science, social studies, maths, Turkish (Baydar \& Şimşek, 2018; Karaçöp, 2016; Alyar \& Doymuş, 2015; Karababa, 2009; Demirbaş, Bozdoğan \& Taşdemir, 2008; Yılar, Şimşek, Topkaya \& Balkaya, 2015; Akçay \& Doymuş, 2014; Şimşek, Yılar \& Küçük, 2013; Şimşek, Doymuş, Doğan \& Karaçöp, 2009; Karaçöp, 2017; Doymuş, 2008; Gündoğdu, Ozan \& Taşgın, 2007). All 12 studies $(n=12)$, except for Karababa (2009), reported a significant effect of CL on pre-service teachers' academic achievement $(n=1)$.

As the studies were investigating the effect of CL, most of the studies were experimental ( $n$ $=2)$ or quasi-experimental $(n=11)$ as is illustrated in Table 2 at the end of the review (also, see Appendix 1). In addition, while 11 studies used a control group in their research (Baydar \& Şimşek, 2018; Karaçöp, 2016; Alyar \& Doymuş, 2015; Karababa, 2009; Şimşek, Doymuş, Doğan \& Karaçöp, 2009; Demirbaş, Bozdoğan \& Taşdemir, 2008; Akçay \& Doymuş, 2014; 
Avc1, N., Aksu, M. (2019). The effect of cooperative learning on primary-elementary pre-service teachers' academic achievement in Turkey: A systematic review. International Journal of Social Sciences and Education Research, 5(2), 122-141.

Karaçöp, 2017; Doymuş, 2008; Gündoğdu, Ozan \& Taşgın, 2007); the other two did not (Yılar, Şimşek, Topkaya \& Balkaya, 2015; Şimşek, Yılar \& Küçük, 2013). They both prefered a within two groups pre-post design different from the rest.

For examining the effect of CL on academic achievement of primary-elementary pre-service teachers various instruments were implemented most of which were prepared by the researchers themselves for particular subject areas. The instruments used were as follow: Baydar and Şimşek (2018), Academic Achievement Test (AAT); Karaçöp (2016), Electrochemistry Achievement Test (EcAT); Alyar and Doymuş (2015) Preliminary Information Test (PIT), Academic Achievement Tests (AAT), The Particulate Nature of Matter Test (PNMT $1,2,3,4)$; Karababa (2009) exams prepared; Demirbaş, Bozdoğan and Taşdemir (2008) AATs; Yılar, Şimşek, Topkaya and Balkaya (2015) Academic Success Tests (ASTs); Akçay and Doymuş (2014) graphic interpretation tests, Success for the Units Module Tests (MDs) ; Şimşek, Y1lar and Küçük (2013) AATs; Şimşek, Doymuş, Doğan and Karaçöp (2009) Thinking of Logical Tests (ToLT), Chemical Equilibrium Achievement Tests (CeAT), Chemical Equilibrium Particulate Nature of Matter Evaluation Test (cePNMET); Karaçöp (2017) Science Laboratory Physic Achievement Test (SLPAT); Doymuş (2008) Chemical Bonding Achievement Test (CBAT); Gündoğdu, Ozan and Taşgın (2007) AATs and Artut and Tarim (2007) AATs as well to examine the effect of CL on pre-service teachers' academic achievement.

With regard to the sample characteristics, all the studies included pre-service teachers from the faculty of education of different public universities including only primary and elementary education programmes $(n=13)$. The studies were conducted on pre-service teachers from departments of primary-elementary education (class teachers) $(n=3)$, science education $(n=6)$, Turkish education $(n=1)$ social studies $(n=3)$. Detailed information is already given in relation to the sample sizes of the studies on Table 2 (see Appendix 1). Based on perused data of the articles drawn to the review, the common themes were identified as can be seen in the fifth column in Table 2 (see Appendix 1) and analyzed in detail there. As an important emphasis, it should be underlined here that some major themes emerge in other themes resprenting the subthemes. Therefore, those studies will be simultaneously reviewed under different major themes as well.

The first theme emerged as "comparison of CL with traditional methods (TMs)" which dwelled on the effectiveness of CL on primary-elementary pre-service teachers' academic achievement via comparing CL with any conventional method $(n=5)$. As there are still many methods and techniques evolving in CL, there is quite a big amount of studies representing different methods of CL. The studies drawn, in this respect, included studies representing different methods examining the effect on achievement. So, the second theme emerged as "comparison of different methods of CL" which searched for the effect of CL on academic achievement via comparing within methods of CL with each other $(n=4)$. The third theme emerged as "Jigsaw as a CL method" which searched for the effect of CL on primary-elementary pre-service teachers' academic achievement by emphasizing Jigsaw as a CL method over some conventional methods $(n=4)$.

\subsection{Comparison of CL with traditional methods (TMS)}

This theme was represented in the studies of Karaçöp (2016); Alyar and Doymuş (2015); Karababa (2009); Demirbaş, Şimşek, Doymuş, Doğan and Karaçöp (2009); Bozdoğan and 
Avc1, N., Aksu, M. (2019). The effect of cooperative learning on primary-elementary pre-service teachers' academic achievement in Turkey: A systematic review. International Journal of Social Sciences and Education Research, 5(2), 122-141.

Taşdemir (2008) and as a subtheme in the third theme (Jigsaw as a CL method) in the studies of Karaçöp (2017); Doymuş (2008); Gündoğdu, Ozan and Taşgın (2007) and Artut and Tarim (2007), $(n=9)$ which is presented in Table 3.

Table 3. Comparison of CL with Traditional Methods (TMs)

\begin{tabular}{|c|c|c|c|c|}
\hline & Theme & Context & Method & Effect \\
\hline Karaçöp (2016) & major & electrochemical cells & STAD & significant \\
\hline $\begin{array}{l}\text { Alyar and Doymuş } \\
(2015)\end{array}$ & major & $\begin{array}{c}\text { particulate nature of } \\
\text { matter }\end{array}$ & LT, RWP, STAD & significant \\
\hline $\begin{array}{l}\text { Şimşek, Doymus, } \\
\text { Doğan and Karaçöp } \\
\text { (2009) }\end{array}$ & major & $\begin{array}{c}\text { chemical equilibrium } \\
\text { unit }\end{array}$ & Jigsaw & significant \\
\hline $\begin{array}{l}\text { Demirbaş, Bozdoğan } \\
\text { and Taşdemir (2008) }\end{array}$ & major & electricity & STAD & significant \\
\hline Karaçöp (2017) & sub-theme & $\begin{array}{l}\text { science teaching labora- } \\
\text { tory courses }\end{array}$ & Jigsaw I & significant \\
\hline Doymuş (2008) & sub-theme & chemical bonding & Jigsaw I & significant \\
\hline Karababa (2009) & major & Turkish syntax & Discussion & $\begin{array}{c}\text { non-significant }(p \\
>.05)\end{array}$ \\
\hline $\begin{array}{l}\text { Gündoğdu, Ozan and } \\
\text { Taşgin (2013) }\end{array}$ & sub-theme & $\begin{array}{c}\text { educational psychology } \\
\text { course }\end{array}$ & Jigsaw I & significant \\
\hline $\begin{array}{l}\text { Artut and Tarim } \\
\text { (2007) }\end{array}$ & sub-theme & maths teaching course & Jigsaw II & significant \\
\hline
\end{tabular}

All the studies in this theme, except for Karababa (2009) reported a significant effect of CL over conventional methods. The study reported robust results because of the random assignment of students to the conditions and the use of the same instructor to teach both of the learning contexts $(\mathrm{p}>.05)$.

As for the contexts, the studies comparing CL to conventional methods were majorly used in science teaching departments: Karaçöp (2016) in electrochemical cells; Alyar and Doymuş (2015) in the particulate nature of matter; Şimşek, Doymuş, Doğan and Karaçöp (2009) in teaching of chemical equilibrium unit; Demirbaş, Bozdoğan and Taşdemir (2008) in the unit of electricity, also as a sub-theme (emerging in Jigsaw theme) Karaçöp (2017) in science teaching laboratory courses; Doymuş (2008) in teaching chemical bonding. The rest of the studies comparing CL to traditional methods were used in different contexts other than science were as follow: Karababa (2009) in teaching Turkish syntax; Gündoğdu, Ozan and Taşgın (2013) in educational psychology course; Artut and Tarim (2007) in maths teaching course.

With regard to the method used, with five studies in which they were used, Jigsaw $(n=5)$ and STAD $(n=2)$ were the ones that were mostly used in examining the effect of CL on achievement of primary- elementary pre-service teachers; in one study, LT (n $=1)$ and RWP (n $=1)$ methods were used together with STAD compared to traditional methods. In addition, as Mayer (2011) took Discussion as an instructional strategy, in one study it was used as method (3-minute discussions), though.

\subsection{Comparison of different methods of $C L$}

$\mathrm{CL}$ is one of the most productive instructional strategies that many methods and techniques were evolved from which is already discussed in the literature review. As for the Turkish literature, there was quite a bulk of studies exploiting those methods and almost newly evolved ones. This review indicated that, with the purpose of investigating the effect of academic achievement 
Avc1, N., Aksu, M. (2019). The effect of cooperative learning on primary-elementary pre-service teachers' academic achievement in Turkey: A systematic review. International Journal of Social Sciences and Education Research, 5(2), 122-141.

on primary-elementary pre-school teachers, interventions were conducted mostly via applying specific methods. In this frame there was a fairly enough variety of methods including STAD, LT, RWP, GI, Jigsaw I and Jigsaw II in 13 studies retrieved to the study. Specificly to this theme, there were four major methods of CL used in comparing the effects of each compared to another which are mainly RWP $(n=4)$; LT $(n=3)$; Jigsaw $(n=3)$; STAD $(n=3)$. The combinations were comprised of STAD vs Jigsaw; Jigsaw vs. RWP; RWP vs. LT; GI vs. RWP; LT vs. RWP vs. STAD; Jigsaw vs. LT.

This theme was represented in the studies of Baydar and Şimşek (2018); Y1lar, Şimşek, Topkaya and Balkaya (2015); Akçay and Doymuş (2014); Şimşek, Yılar and Küçük (2013); and represented as a sub-theme in the studies of Alyar and Doymuş (2015); Şimşek, Doymuş, Doğan and Karaçöp (2009) ( $n=5)$ as in Table 4.

Table 4. Comparison of different CL Methods

\begin{tabular}{|c|c|c|c|c|}
\hline & Theme & Context & Method & Effect \\
\hline Baydar and Şimşek (2018) & major & $\begin{array}{l}\text { principles and meth- } \\
\text { ods of instruction }\end{array}$ & $\begin{array}{l}\text { Jigsaw vs. } \\
\text { STAD }\end{array}$ & $\begin{array}{l}\text { significant } \\
\text { STAD }>\text { Jigsaw }\end{array}$ \\
\hline $\begin{array}{l}\text { Yilar, Şimşek, Topkaya } \\
\text { and Balkaya (2015) }\end{array}$ & major & $\begin{array}{l}\text { principles and meth- } \\
\text { ods of instruction }\end{array}$ & Jigsaw vs. RWP & $\begin{array}{l}\text { non-significant } \\
p>.05\end{array}$ \\
\hline Akçay and Doymuş (2014) & major & $\begin{array}{l}\text { unit of force and } \\
\text { motion }\end{array}$ & $\begin{array}{l}\text { GI vs. RWP vs. } \\
\text { LT }\end{array}$ & $\begin{array}{l}\text { significant } \\
\text { RWP }>\text { LT and GI }\end{array}$ \\
\hline $\begin{array}{l}\text { Şimşek, Y1lar and Küçük } \\
\text { (2013) }\end{array}$ & major & $\begin{array}{l}\text { social psychology } \\
\text { course }\end{array}$ & GI vs. RWP & $\begin{array}{l}\text { significant } \\
\text { RWP }>\text { GI }\end{array}$ \\
\hline Alyar and Doymuş (2015) & sub-theme & $\begin{array}{l}\text { particulate nature of } \\
\text { matter }\end{array}$ & $\begin{array}{l}\text { LT vs. RWP vs. } \\
\text { STAD }\end{array}$ & $\begin{array}{l}\text { non-significant on } \\
\text { inferential statistics } \\
\text { according to descrip- } \\
\text { tive statistics, } \\
\text { STAD }>\text { RWP }>\text { LT }\end{array}$ \\
\hline $\begin{array}{l}\text { Şimşek, Doymuş, Doğan } \\
\text { and and Karaçöp (2009) }\end{array}$ & sub-theme & $\begin{array}{l}\text { unit of chemical } \\
\text { equilibrium }\end{array}$ & Jigsaw vs. LT & $\begin{array}{l}\text { significant } \\
\text { Jigsaw }>\text { LT }\end{array}$ \\
\hline
\end{tabular}

Four of the studies reported significant effect; that is as a result of the comparison of different CL methods, the intervention in one method resulted in higher academic achievements in primary-elementary pre-service teachers in the studies of Baydar and Şimşek (2018); Akçay and Doymuş (2014); Şimşek, Yılar and Küçük (2013); and Şimşek, Doymuş Doğan and Karaçöp (2009) $(n=4)$. While Baydar and Şimşek conducted their study to compare Jigsaw and STAD in teaching principles and methods course found that STAD was more effective than Jigsaw on students' academic achievement; Akçay and Doymuş (2008) conducted their study to determine the effect of Group Investigation (GI), Learning Together (LT) and Reading-Writing-Presenting (RWP) in the unit of force and motion in general physics course and they found that RWP resulted in higher academic achievements. Besides, Şimşek, Yılar and Küçük (2013) conducted their study to examine the effects of Group Investigation (GI) and Reading-Writing-Presenting (RWP) in social psychology course and found that RWP increased pre-service teachers' academic achievements significantly. Another study finding a significant effect on achievement of pre-service teachers was Şimşek, Doymuş, Doğan and Karaçöp's (2009) study in which Learning Together (LT) and Jigsaw methods were used (compared to a control group of conventional method) in teaching chemical equilibrium unit. The results were in favor of the Jigsaw group. That is, in four studies one method of CL proved to yield better results over primary-elementary pre-service teachers $(n=4)$. On the other hand, two studies reported non-significant effects. Yet, the studies of Yılar, Şimşek, Topkaya and Balkaya (2015); Alyar and Doymuş (2015) stat- 
Avc1, N., Aksu, M. (2019). The effect of cooperative learning on primary-elementary pre-service teachers' academic achievement in Turkey: A systematic review. International Journal of Social Sciences and Education Research, 5(2), 122-141.

ed that despite the non-significant difference in comparison of the methods to each other, $\mathrm{CL}$ methods still had an effect on students' academic achievements.

In sum, though there were two studies finding no significant difference, the authors stated that CL had an effect on students' academic achievement. So, the fact that a method did not prove superiority to another method in a strategy was not to be generalized to the strategy itself and also there might be other variables overlooked affecting the intervention.

\subsection{Jigsaw as a CL method}

As a CL method Jigsaw is one of the most represented one both in the worldwide and Turkish literature. Among its variations of Jigsaw I, II, III and IV, in this review, Jigsaw is represented by Jigsaw I and Jigsaw II. As the third theme, Jigsaw as a CL method emerged in the studies of Karaçöp (2017); Doymuş (2008); Gündoğdu, Ozan, Taşgın (2013); Artut and Tarim (2007); as a sub-theme in the studies of Baydar and Şimşek (2018); Şimşek, Doymuş, Doğan and Karaçöp (2009); Yılar, Şimşek, Topkaya and Balkaya (2015) $(n=7)$.

Studies reporting a significant effect were Baydar and Şimşek (2018); Karaçöp (2017); Doymuş (2008); Gündoğdu, Ozan, Taşgın (2013); Artut and Tarim (2007); Şimşek, Doymuş, Doğan and Karaçöp (2009). Both Baydar and Şimşek (2018) conducting their study in the context of teaching principles and methods compared Jigsaw I to another method; and Karaçöp (2017) in the context of science laboratory practice; Doymuş (2008) in a context of chemical bonding; Gündoğdu, Ozan and Taşgın (2013) in the context of educational psychology course and Şimşek, Doymuş, Doğan and Karaçöp (2009) conducting their studies comparing Jigsaw to conventional methods, all reported a significant effect on academic achievement of pre-service primary-elementary teachers. Only Artut and Tarim (2007) in their study, different from the rest, implemented Jigsaw II in the context of maths teaching, also reporting a significant effect of Jigsaw on academic achievement $(n=6)$ as in Table 5.

Table 5. Jigsaw as a CL Method

\begin{tabular}{|c|c|c|c|c|}
\hline & Theme & Context & Method & Effect \\
\hline Karaçöp (2017) & major & $\begin{array}{l}\text { science laboratory } \\
\text { practice }\end{array}$ & Jigsaw I & significant \\
\hline Doymuş (2008) & major & chemical bonding & Jigsaw I & significant \\
\hline $\begin{array}{l}\text { Gündoğdu, Ozan and } \\
\text { Taşgın (2013) }\end{array}$ & major & $\begin{array}{l}\text { educational psycholo- } \\
\text { gy course }\end{array}$ & Jigsaw I & significant \\
\hline Artut and Tarim (2007) & major & math teaching & Jigsaw II & significant \\
\hline Baydar and Şimşek (2018) & sub-theme & $\begin{array}{l}\text { principles and meth- } \\
\text { ods of instruction }\end{array}$ & STAD vs. Jigsaw I & $\begin{array}{l}\text { significant } \\
\text { STAD }>\text { Jigsaw }\end{array}$ \\
\hline $\begin{array}{l}\text { Y1lar, Şimşek, Topkaya } \\
\text { and Balkaya (2015) }\end{array}$ & sub-theme & $\begin{array}{l}\text { principles and meth- } \\
\text { ods of instrcution }\end{array}$ & Jigsaw vs. RWP & non-significant \\
\hline $\begin{array}{l}\text { Şimşek, Doymuş, Doğan } \\
\text { and Karaçöp (2009) }\end{array}$ & sub-theme & $\begin{array}{l}\text { unit of chemical } \\
\text { equilibrium }\end{array}$ & Jigsaw I (vs. LT) & $\begin{array}{l}\text { significant } \\
\text { Jigsaw }>\text { LT }\end{array}$ \\
\hline
\end{tabular}

The only study with a non-significant effect was Yılar, Şimşek, Topkaya, Balkaya's (2015) study in which in fact it was emphasized that, though there was not a significant difference between the compared methods (Jigsaw to RWP), the results indicated that CL in general, had an effect on students' academic achievements $(n=1)$. 
Avc1, N., Aksu, M. (2019). The effect of cooperative learning on primary-elementary pre-service teachers' academic achievement in Turkey: A systematic review. International Journal of Social Sciences and Education Research, 5(2), 122-141.

\section{Discussion}

As a result of the review of the studies retrieved, with the purpose of examining the effect of CL on primary-elementary pre-service teachers' academic achievement, there emerged three major themes which are (a) comparison of CL to traditional methods (TMs); (b) comparison of different methods of CL and (c) Jigsaw as a CL method. The overall results of all three themes indicated a significant effect.

Confirming the effects of CL by wide spanned research Johnson and Johnson (1989) reported that "working together to achieve a common goal produces higher achievement and greater productivity than does working alone" (p. 12) as well as contributing to "process gain", "group to individual" than do the competitive or individualistic learning. In this sense, the results of this national review carried out with the purpose of examining the effect of CL on primaryelementary pre-service teacher's academic achievement in Turkey, to a large extent were in line with the results of Orprayoon (2014); Tran and Lewis' (2012) studies in international literature. There were also studies regarding non-significant differences, though $(n=2)$. One of those studies was Yılar, Şimşek, Topkaya and Balkaya's (2015) which majorly as a theme was represented in "comparison of different CL methods" comparing Jigsaw to RWP; and the other study with a non-significant difference was of Alyar and Doymuş (2015) comparing LT, RWP and STAD which in fact both examined the superiority -if exist- of any method over another within CL. Yet, although the results yielded non-significant differences with regard to the superiority of one over another, the authors of those studies reported CL improving learning and having a positive effect on academic achievement.

Only one study (Karababa, 2009) which was in the "comparison of CL to traditional methods (TMs) theme" put forward the claim of non-significant effect supporting having robust results because of random assignment of the students to conditions, and the use of the same instructor to teach both of the learning contexts. Though the study was of a valuable contribution to the literature, taking into account the limitations of the study which were identified as limited timing of application (two hours of application) and that the examinations were not for assessing what was kept in students' long-term memory, the results as stated by the author, were rather difficult to be generalized to the literature. So, as is stated by Johnson and Johnson (1999); Johnson, Johnson and Holubec (1991); Kagan (1994) for long term success the basic principles which are positive interdependence; individual accountability; face-to-face promotive interaction; appropriate use of social, interpersonal, collaborative and small group skills and group processing are to be systematically structured to help ensuring cooperative efforts and enabling the disciplined implementation. In this sense, there might have emerged some slight mishaps during the implementation of one of the principles mentioned from the literature above or some other unseen variables might have intervened into the results. On the other hand, the rest of the studies in this theme indicated a significant difference compared to traditional methods. The studies in this theme were conducted mostly in science teaching courses which was the same both for (b) comparison of different CL methods and (c) Jigsaw as a CL method. This could have stemmed from the difficulty of grasping the concepts and difficult subjects in science working alone via individualized work which is central in teacher or lecture-based way of teaching of which the main purpose is delivering the topic via lecturing, putting learners generally as passive. In cooperative learning, on the contrary, students are considered active participants of the groups giving responsibility to the students both for their own and their mates' learning. So 
Avc1, N., Aksu, M. (2019). The effect of cooperative learning on primary-elementary pre-service teachers' academic achievement in Turkey: A systematic review. International Journal of Social Sciences and Education Research, 5(2), 122-141.

based on the results of this national review, it can be said that regardless of via whichever method it is accomplished, compared to conventional methods, cooperative learning resulted in significant effect on achievement.

Finally, in the theme of "Jigsaw as a CL method" as well, significant effect was found except for two studies $(n=2)$. The thing is that, the study of Yılar, Şimşek, Topkaya and Balkaya (2015) there was represented as a sub-theme and, in fact the study's major theme was "comparison of different CL methods". Yet, despite the non-significant difference in this theme for the sake of Jigsaw (compared to LT), both cooperative methods were reported have an effect on academic achievement. And the study by Baydar and Şimşek (2018) in fact was represented in the "comparison of methods of CL" and proved significance of STAD over Jigsaw. Yet, this study still proves a significant difference on student achievement. Also, because of the significant differences of the rest five studies in this theme, it could be stated that Jigsaw as a CL method had a significant effect on achievement $(n=6)$ which also is in line with the study of Haryano (2015) in international literature. Developed by Eliot Aronson in 1978, Jigsaw is "one of the best ways to actualize learning and social behaviors" as is stated by Karaçöp (2017). This could be the main reason of Jigsaw to prove significant effect particularly in science subjects in the studies of Karaçöp (2017) in the context of science laboratory practice, Doymuş (2008) in the context of chemical bonding; Şimşek, Doymuş, Doğan and Karaçöp (2009) in the context of chemical equilibrium. In Jigsaw, students need to cooperate with others in order to accomplish the learning tasks as students' efforts result in both group and individualistic gains. Thus, taskinterdepended, reward interdependence (in Jigsaw II) and individual accountability go hand in hand in this method contributing to the learning creating cohesiveness among learners. Although the method is found particularly helpful in science and math teaching as particularly in learning the difficult concepts, cooperating becomes a vital need rather than a requirement, it is applicable in any subject area yielding effective results in social sciences as well, like in the study of Gündoğdu, Ozan, Taşgin (2013).

In sum, as an overall expression, it can be stated that CL has a significant effect on primaryelementary pre-service teachers academic achievement overlapping with the results both national and international literature regarding the comparison of CL with traditional methods.

\section{Conclusion}

As Millis (2010) cited from Nilson (2003) "old teaching paradigms and habits die hard. If we had no trouble learning with them when we were in college, we can't understand why our students do" (p. 128) points to the major concern of this review. If pre-service teachers do not understand how achievement can be sustained by experiencing the strategy itself, to what extent they would be equipped to implement it when they go into the actual classroom remains a controversial issue. Under the circumstances of being taught via a teacher-centered approach, it would not be very easy for the pre-service teachers to make use of learner-based instruction. In this sense, based on the review it can be said that there is a big amount of representative studies indicating promising efforts at varied faculties of education.

As the purpose of this review was to display the effect of CL on primary-elementary preservice teachers' academic achievement, in all the three themes emerged, significant effect of academic achievement was reported. This also is kind of a translation of the efforts of the facul- 
Avc1, N., Aksu, M. (2019). The effect of cooperative learning on primary-elementary pre-service teachers' academic achievement in Turkey: A systematic review. International Journal of Social Sciences and Education Research, 5(2), 122-141.

ties with intentions of equipping their future teachers when Turkey adopted Constructivism as an educational approach in 2005 which is the major theory underlying CL.

First of all, as a result of the findings of the theme emerging as "comparison of CL to traditional methods (TMs)" it can be concluded that CL has a significant effect on primaryelementary teachers' academic achievement. In today's conditions of our faculties of education in Turkey, the ballooning enrollments of large numbers of students, challenges most faculty members to teach via lecturing, which means the students are to deal with complex content mostly by themselves. There, in this sense, cooperative learning in the international literature based on researches is pointed as an effective solution for large class sizes both satisfying the deepest longings of the teachers and equipping the future teachers with the skills they would need as students are pushed from being passive to active (Millis, 2010, p. 6).

Secondly, as a result of the review of the studies in the theme of "comparison of different methods of CL" it can be concluded that whichever method in CL it is, though different methods and techniques can be effective in different conditions, results in significant effect on primary-elementary preservice teachers' academic achievement.

Thirdly, as a result of the review of the studies in the theme of "Jigsaw as a CL method", it can be concluded that Jigsaw (mostly compared to the traditional methods) has a significant effect on academic achievement of primary-elementary pre-service teachers. According to Millis (2010) the growing literature changed the meaning of learning as "...stabilizing through repeated use, certain, appropriate and desirable synapses in the brain" (Leamnson, 2000, 5) which means "activating students' engagements and cooperative interactions are essential" (pp. 3-5). Jigsaw in this sense by taking the students each as a complement of a Jigsaw puzzle, seems to be one of the most appropriate methods to take students to pull the students to the active level.

Further, in relation to the contexts as a result of the review it can be concluded that most of the studies were conducted in science teaching in which concepts and subjects are usually difficult to deal with via individualized work in the classroom. Specifically, this point is of great meaning for the primary-elementary pre-service teachers as in the context of primaryelementary level, teaching concepts and topics of science which are more abstract or difficult to learn because of the developmental stages of the learners, requires them to be well-equipped with cooperative learning methods. Also, the sensitivity of the age group at primary-elementary school level requires well-developed skills of teachers which would both enhance learning and develop social relationships among their students. There again, cooperative learning would pave the way of prospective teachers finding solutions for their classrooms. Also, the recent refugee problem experienced in Turkey is the signaling factor that in a couple of years our newly graduate teachers would have to deal with in their classrooms. With regard to this also, cooperative learning can be an alternative solution on behalf of the learners as "cooperative learning puts emphasis on building community in classes, provides teachers with very specific tools - the structures and the management approaches for maintaining maximized learning and fostering increased self-esteem, respect for others and civility" (Millis, 2010, p. 6).

\section{Future implications}

The reviews in another way contribute in reflecting upon the missing areas in the literature which is of central importance for enhancing studies and developing new perspectives. Though 
Avc1, N., Aksu, M. (2019). The effect of cooperative learning on primary-elementary pre-service teachers' academic achievement in Turkey: A systematic review. International Journal of Social Sciences and Education Research, 5(2), 122-141.

there is a huge number of studies representing cooperative learning, in most of the studies Jigsaw, RWP or STAD as a method are preferred. This in a sense provides a chance for improving the appropriate use of the related methods and giving ideas for the situations in which they prove to be effective. Yet, there should other methods be involved, as well. Secondly, the literature involves enough amount of studies for drawing lots of systematic reviews: for instance, in relation to the contribution of CL in improving specific skills (writing, science process, defining, retrieval, retention, interpretation etc.) which does not exist in the literature can be exploited.

What is more important is that in international literature, as Millis (2010) states as well, technology and cooperative learning are natural partners. Yet, ten fact that the studies combining cooperative learning strategy with technology in our national literature are less than few, paves the way indeed for further research and is open to develop particularly in an era in which teachers have serious troubles in incorporating technology into their classes.

As a final word, as initial teacher education is of prime significance for evolving wellequipped teachers with the skills adaptive to the everchanging educational settings, the teacher education programs would consider such studies as major sources of information in improving their syllabi and developing new perspectives for transforming the future teachers on a sound ground.

\section{References}

Akçay, N. O. \& Doymuş, K. (2014). The effect of different methods of cooperative learning model on academic achievement in physics. Journal of Turkish Science Education, 11(4), 17-30. DOI: 10.12973/tused.10124a.

Alyar, M. \& Doymuş, K. (2015). The effects of cooperative learning methods on the understanding of the particulate nature of matter. Ahi Evran University Journal of Kirşehir Faculty of Education, 16(2), 371-389.

Baydar, A. \& Şimşek, U. (2018). The impact of Jigsaw and STAD on social studies pre-service teachers' academic achievement. Studies in Educational Research and Development, 2(1).

Artut, P. D. \& Tarim, K. (2007). The effectiveness of jigsaw II on prospective elementary school teachers. Asia-Pacific Journal of Teacher Education, 35(2), 129-141. DOI: 10.1080/13598660701268551.

Çınar, O., Teyfur, E. \& Teyfur, M. (2006). Primary school teachers and administrators views about constructivist education approach and programs. Inönü University Journal of Faculty of Education, (7)(11), 47-64.

Demirtaş, M., Bozdoğan, A. E. \& Taşdemir, A. (2008). The effect of cooperative learning on the development of students' academic achievement in the physics laboratory course. OMU Journal of Education, 26, 25-34.

Doymuş, K. (2008). Teaching chemical bonding through Jigsaw cooperative learning. Research in Science \& Technological Education, 26(1), pp. 47-57. DOI: 10.1080/02635140701847470.

Erkoç, A., \& Dinç Artut P. (2016). The effect of the Team-Assisted Individualization technique on eighth grade students' geometry achievement and retention. H. U. Journal of Education, 31(1). DOI: 10.16986/HUJE.2015013972.

Gündoğdu, K., Ozan, C., \& Taşgın, A. (2013). The effect of the Jigsaw technique implementation on prospective teachers' academic achievements. International Journal of Psycho-Educational Sciences, $4(4), 61-74$.

Haryono (2015). Learning achievement improvement efforts course learn and learning using the Jigsaw Method and Card Media in stkip pgri ngawi 2014/2015 academic year. Journal of Education and Practice, 6(30), 94-102. 
Avc1, N., Aksu, M. (2019). The effect of cooperative learning on primary-elementary pre-service teachers' academic achievement in Turkey: A systematic review. International Journal of Social Sciences and Education Research, 5(2), 122-141.

Johnson, D. W. \& Johnson, R. T. (1989). Cooperation and competition: Theory and research. Edina, $\mathrm{MN}$ : Interaction Book Company.

Johnson, D. W. \& Johnson R. T. (2017). The use of cooperative procedures in teacher education and professional development. Journal of Education for Teaching, 43(3), 284-295, DOI: $10.1080 / 02607476.2017 .1328023$

Jolliffe, W. \& Snaith, J. (2017) Developing cooperative learning in initial teacher education: indicators for implementation. Journal of Education for Teaching, 43(3), 307-315, DOI: $10.1080 / 02607476.2017 .1319507$

Kagan, S. (1994). Cooperative Learning, Resources for Teachers. San Juan Capistrano, CA: Kagan Cooperative Learning.

Karababa, Z. C. C. (2009). Effects of coopeartive learning on prospective teachers' achievement and social interactions. H.U. Journal of Education, 36, 32-40.

Karaçöp, A. (2017). The effects of using jigsaw method based on cooperative learning model in the undergraduate science laboratory practices. Universal Journal of Educational Research, 5(3), pp. 420434. DOI: 10.13189/ujer.2017.050314.

Karaçöp, A. (2016). Effects of student teams-achievement divisions Cooperative Learning with models on students' understanding of electrochemical cells. International Education Studies, 9(11), DOI:10.5539/ies.v9n11p104.

Millis, B. J. (Ed.) (2010). Cooperative learning in higher education: across the disciplines, across the academy. Sterling, Virginia: Stylus Publishing, LLC.

MoNE (2012). 12 years of compulsory education: Questions and Answers. (Retrieved from) http://www.meb.gov.tr/duyurular/duyurular2012/12Yil_Soru_Cevaplar.pdf

Najmonnisa \& Saad, I. (2017). The role of cooperative learning method in teaching of science subject at elementary school level: An experimental study. Bulletin of Education and Research, August, 39(2), $1-17$.

Orprayoon, S. (2014). Effects of cooperative learning on learning achievement and group working behavior of junior students in modern french literature course. The Journal of Effective Teaching, 4(1), 8098.

Slavin, R. E., (1980). Cooperative learning. Review of Educational Research, 50(2), 315-342. DOI: $10.3102 / 00346543050002315$.

Slavin, R. E. (2008). Cooperative learning, success for all, and evidence-based reform in education. Éducation et didactique, 2(2), pp. 151-159, DOI: 10.4000/ educationdidactique.334

Slavin, R.E. (2011). Instruction Based on Cooperative Learning. In R. Mayer (Ed.), Handbook of research on learning and instruction. London: Taylor \& Francis.

Şimşek, U., Yılar, B. \& Küçük, B. (2013). The effects of cooperative learning methods on students' academic achievements in social psychology lessons. International Journal on New Trends in Education and Their Implications, 4(3), 4-9.

Şimşek, Ü., Doymuş, K., Doğan, A. \& Karaçöp, A. (2009). Effects of two different cooperative learning techniques on students' academic achievement of chemical equilibrium topics. GÜ Journal of Education, 29(3),763-791.

Tran, V. D. \& Lewis, R. (2012). Effects of cooperative learning on students at an giang university in Vietnam. International Education Studies, 5(1), 86-99. http://dx.doi.org/10.5539/ies.v5n1p86

Varışoğlu, B. (2016). Influence of cooperative integrated reading and composition technique on foreign students' reading and writing skills in Turkish. Education Research and Reviews, 11(12), 1168-1179. DOI: $10.5897 / E R R 2016.2744$.

Yılar, M. B., Şimşek, U., Topkaya, Y. \& Balkaya, İ. S. (2015). Effects of cooperative learning methods on social studies undergraduate students' academic achievement. Uşak University Journal of Social Sciences, 8(4), 297-315. 
Avc1, N., Aksu, M. (2019). The effect of cooperative learning on primary-elementary pre-service teachers' academic achievement in Turkey: A systematic review. International Journal of Social Sciences and Education Research, 5(2), 122-141.

\section{Appendix 1}

Table 2: Studies included into systematic review

\begin{tabular}{|c|c|c|c|c|}
\hline Publication & Method & Purpose and context & Results & Theme \\
\hline $\begin{array}{l}\text { Karaçöp } \\
(2016)\end{array}$ & $\begin{array}{l}\text { Quasi- } \\
\text { experimental }\end{array}$ & $\begin{array}{l}\text { To determine the effect of Student Teams- } \\
\text { Achievement Divisions cooperative } \\
\text { learning with models on academic } \\
\text { achievements of undergraduate university } \\
\text { students attending classes in which the } \\
\text { electrochemical cells }(n=70) \text {. } \\
\text { The Departmen of Science Education } \\
\text { (Freshmen) }\end{array}$ & $\begin{array}{l}\text { The results indicated that } \\
\text { teaching electrochemical } \\
\text { cells via STAD with model } \\
\text { method was more effective } \\
\text { than the traditional teaching } \\
\text { method and only STAD in } \\
\text { increasing academic } \\
\text { achievement. }\end{array}$ & $\begin{array}{l}\text { Comparison } \\
\text { of CL with } \\
\text { TMs. }\end{array}$ \\
\hline $\begin{array}{l}\text { Alyar and } \\
\text { Doymuş } \\
(2015)\end{array}$ & $\begin{array}{l}\text { Quasi- } \\
\text { experimental }\end{array}$ & $\begin{array}{l}\text { To determine the effect of learning to- } \\
\text { gether (LT), reading-writing-presenting } \\
\text { (RWP) and student teams-achievement } \\
\text { divisions methods in understanding of } \\
\text { "The Particulate Nature of Matter" on } \\
\text { students'academic achievement ( } n=96 \text { ). } \\
\text { The Department of Science Education } \\
\text { (Freshmen) }\end{array}$ & $\begin{array}{l}\text { According to the results in } \\
\text { the understanding of "The } \\
\text { Particulate Nature of Mat- } \\
\text { ter", CL was more effective } \\
\text { than the teacher-centered } \\
\text { teaching method (TM). }\end{array}$ & $\begin{array}{l}\text { Comparison } \\
\text { of CL with } \\
\text { TMs. (LT, } \\
\text { RWP, STAD } \\
\text { vs. TMs) }\end{array}$ \\
\hline $\begin{array}{l}\text { Karababa } \\
(2009)\end{array}$ & $\begin{array}{l}\text { Quasi- } \\
\text { experimental }\end{array}$ & $\begin{array}{l}\text { To examine the effects of CL (via 3- } \\
\text { minute discussions) on achievement of } \\
\text { Turkish prospective elementary school } \\
\text { teachers' learning of the content of Turk- } \\
\text { ish Syntax course and on their social } \\
\text { interaction in the classroom }(n=80) \text {. } \\
\text { The Department of Primary Education } \\
\text { (registered students) }\end{array}$ & $\begin{array}{l}\text { The results indicated no } \\
\text { significant effect on academ- } \\
\text { ic achievement. Yet, students } \\
\text { in the cooperative condition } \\
\text { were more involved in posi- } \\
\text { tive and supportive relation- } \\
\text { ships with their classmates } \\
\text { compared to students in the } \\
\text { individualistic learning. }\end{array}$ & $\begin{array}{l}\text { Comparison } \\
\text { of CL with } \\
\text { TMs (Discus- } \\
\text { sion vs. TMs) }\end{array}$ \\
\hline $\begin{array}{l}\text { Şimşek, } \\
\text { Doymuş, } \\
\text { Doğan and } \\
\text { Karaçöp } \\
(2009)\end{array}$ & $\begin{array}{l}\text { Quasi- } \\
\text { experimental }\end{array}$ & $\begin{array}{l}\text { To determine the effects of Traditional } \\
\text { Teaching Method with Jigsaw and Learn- } \\
\text { ing Together (LT) methods used in the } \\
\text { implementation of CL, on the academic } \\
\text { achievement of the students participating } \\
\text { the teaching of chemical equilibrium unit } \\
\text { ( } \mathrm{n}=116 \text { ). } \\
\text { The Department of Science Education } \\
\text { (Freshmen) }\end{array}$ & $\begin{array}{l}\text { The results showed that } \\
\text { Jigsaw and LT methods were } \\
\text { more successful than the } \\
\text { Traditional Method (TM). }\end{array}$ & $\begin{array}{l}\text { Comparison } \\
\text { of CL with } \\
\text { TMs. (CL vs. } \\
\text { TMs) } \\
\text { Comparison } \\
\text { of different } \\
\text { methods of } \\
\text { CL (Jigsaw } \\
\text { vs. LT) }\end{array}$ \\
\hline $\begin{array}{l}\text { Demirbaş, } \\
\text { Bozdoğan } \\
\text { and Taşdemir } \\
(2008)\end{array}$ & Experimental & $\begin{array}{l}\text { To determine the effect of CL on stu- } \\
\text { dents' achievement in the chapter "Elec- } \\
\text { tricity" in the course of Physics Laborato- } \\
\text { ry II compared to the traditional methods } \\
(n=67) \text {. } \\
\text { The Department of Science Education } \\
\text { (Freshmen) }\end{array}$ & $\begin{array}{l}\text { As a result of the study, it } \\
\text { was seen that there is a } \\
\text { significant difference be- } \\
\text { tween the students' achieve- } \\
\text { ment pre-test scores and } \\
\text { final-test scores. }\end{array}$ & $\begin{array}{l}\text { Comparison } \\
\text { of CL with } \\
\text { TMs (STAD } \\
\text { vs. TMs) }\end{array}$ \\
\hline $\begin{array}{l}\text { Baydar and } \\
\text { Simşek } \\
(2018)\end{array}$ & $\begin{array}{l}\text { Quasi- } \\
\text { experimental }\end{array}$ & $\begin{array}{l}\text { To compare two cooperative learning } \\
\text { methods, jigsaw and student teams } \\
\text { achievement divisions (STAD), in terms } \\
\text { of their effects on social studies pre- } \\
\text { service teachers' academic achievement. } \\
\text { Department of Social Studies Education } \\
(n=40)\end{array}$ & $\begin{array}{l}\text { The research indicated that } \\
\text { STAD was more effective } \\
\text { than jigsaw on social studies } \\
\text { pre-service teachers' academ- } \\
\text { ic achievement. }\end{array}$ & $\begin{array}{l}\text { Comparison } \\
\text { of different } \\
\text { methods of } \\
\text { CL (STAD vs. } \\
\text { Jigsaw) }\end{array}$ \\
\hline $\begin{array}{l}\text { Yılar, } \\
\text { Şimşek, } \\
\text { Topkaya and } \\
\text { Balkaya } \\
(2015)\end{array}$ & Experimental & $\begin{array}{l}\text { To determine and compare the effect of } \\
\text { Jigsaw and Reading-Writing-Presenting } \\
\text { (RWP) used in the application of CL on } \\
\text { academic success in the course of Princi- } \\
\text { ples and Methods of Instructions Course } \\
\text { ( } n=85 \text { ). } \\
\text { Department of Social Studies Education } \\
\text { (Sophomores) }\end{array}$ & $\begin{array}{l}\text { Cooperative methods had an } \\
\text { effect on students' academic } \\
\text { achievements, but there was } \\
\text { no significant difference } \\
\text { between pre-test and post-test } \\
\text { scores of students of Jigsaw } \\
\text { and Reading-Writing- } \\
\text { Presenting (RWP) groups } \\
\text { while they compare. }\end{array}$ & $\begin{array}{l}\text { Comparison } \\
\text { of different } \\
\text { methods of } \\
\text { CL (Jigsaw } \\
\text { vs. RWP) }\end{array}$ \\
\hline
\end{tabular}


Avc1, N., Aksu, M. (2019). The effect of cooperative learning on primary-elementary pre-service teachers' academic achievement in Turkey: A systematic review. International Journal of Social Sciences and Education Research, 5(2), 122-141.

\begin{tabular}{|c|c|c|c|c|}
\hline $\begin{array}{l}\text { Akçay and } \\
\text { Doymuş } \\
(2014)\end{array}$ & $\begin{array}{l}\text { Quasi- } \\
\text { experimental }\end{array}$ & $\begin{array}{l}\text { To determine the effect of group investi- } \\
\text { gation, learning together and reading- } \\
\text { writing-presenting (RWP) methods on } \\
\text { students' academic achievements in the } \\
\text { unit of "Force and Motion" in general } \\
\text { physics course }(n=121) \text {. } \\
\text { The Department of Science Education } \\
\text { (Freshmen) }\end{array}$ & $\begin{array}{l}\text { The results indicated that } \\
\text { teaching of force and motion } \\
\text { subjects in RWPG was more } \\
\text { effective than the other } \\
\text { groups. }\end{array}$ & $\begin{array}{l}\text { Comparison } \\
\text { of different } \\
\text { methods of } \\
\text { CL (LT vs. } \\
\text { RWP) }\end{array}$ \\
\hline $\begin{array}{l}\text { Şimşek, Yılar } \\
\text { and } \\
\text { Küçük, } \\
(2013)\end{array}$ & $\begin{array}{l}\text { Quasi- } \\
\text { experimental }\end{array}$ & $\begin{array}{l}\text { To investigate the effects of Group Inves- } \\
\text { tigation (GI) and the Reading-Writing- } \\
\text { Presenting (RWP) method in cooperative } \\
\text { learning on students' comprehension of } \\
\text { social psychology lesson. ( } n=107) \\
\text { Department of Social Studies Education } \\
\text { (Registered students) }\end{array}$ & $\begin{array}{l}\text { The results obtained showed } \\
\text { that the Reading Writing } \\
\text { Presenting method has a } \\
\text { more positive effect on } \\
\text { increasing students'academic } \\
\text { knowledge and achievements } \\
\text { in social psychology lesson } \\
\text { than the Group Investigation } \\
\text { method. }\end{array}$ & $\begin{array}{l}\text { Comparison } \\
\text { of different } \\
\text { methods of } \\
\text { CL (GI vs. } \\
\text { RWP) }\end{array}$ \\
\hline $\begin{array}{l}\text { Karaçöp } \\
(2017)\end{array}$ & $\begin{array}{l}\text { Quasi- } \\
\text { experimental }\end{array}$ & $\begin{array}{l}\text { To determine the influence of a Jigsaw } \\
\text { method based on prospective science } \\
\text { teachers' achievements of physics in } \\
\text { science teaching laboratory practice } \\
\text { courses }(n=48) \text {. } \\
\text { The Department of Science Education ( } 3^{\text {rd }} \\
\text { Grade) }\end{array}$ & $\begin{array}{l}\text { The results indicated that the } \\
\text { student teachers had higher } \\
\text { levels of achievement in } \\
\text { physics topics which were } \\
\text { taught than the confirmatory } \\
\text { laboratory method. }\end{array}$ & $\begin{array}{l}\text { Jigsaw Com- } \\
\text { parison of CL } \\
\text { with TMs. } \\
\text { (Jigsaw vs. } \\
\text { TMs) } \\
\text { Jigsaw I }\end{array}$ \\
\hline $\begin{array}{l}\text { Doymuş } \\
(2008)\end{array}$ & $\begin{array}{l}\text { Quasi- } \\
\text { experimental }\end{array}$ & $\begin{array}{l}\text { To examine the effectiveness of Jigsaw in } \\
\text { teaching chemical bonding in the general } \\
\text { chemistry course }(n=36) \text {. } \\
\text { Department of Primary Science Education } \\
\text { (Registered students) }\end{array}$ & $\begin{array}{l}\text { The results indicated that the } \\
\text { students in the Jigsaw group } \\
\text { were more successful than } \\
\text { those in the non-jigsaw group } \\
\text { (the traditional method } \\
\text { group). }\end{array}$ & $\begin{array}{l}\text { Comparison } \\
\text { of CL with } \\
\text { TMs (Jigsaw } \\
\text { vs. TMs) }\end{array}$ \\
\hline $\begin{array}{l}\text { Artut } \\
\text { andTarim } \\
(2007)\end{array}$ & $\begin{array}{l}\text { Quasi- } \\
\text { experimental }\end{array}$ & $\begin{array}{l}\text { To explore the use of Jigsaw II with } \\
\text { prospective elementary teachers (PTs) on } \\
\text { their academic success at Math teaching } \\
\text { course (MTC), }(n=81) \text {. } \\
\text { The Department of Primary Education } \\
\left(3^{\text {rd }} \text { Grade }\right)\end{array}$ & $\begin{array}{l}\text { Jigsaw II had a positive } \\
\text { effect on PTs academic } \\
\text { success as well as on their } \\
\text { views regarding the method } \\
\text { itself. }\end{array}$ & $\begin{array}{l}\text { Jigsaw II } \\
\text { Comparison } \\
\text { of CL with } \\
\text { TMs (Jigsaw } \\
\text { II vs. TMs) }\end{array}$ \\
\hline
\end{tabular}

